Comunicação e Sociedade, vol. 15, 2009, pp. 43-63

\title{
Between display and deliberation: analyzing TV news as communicative architecture*
}

Simon Cottle**

Mugdha Rai***

\begin{abstract}
Television journalism serves to display and deliberate consent and conflict in the contemporary world and it does so through a distinctive 'communicative architecture' structured in terms of a repertoire of 'communicative frames'. This proves consequential for the public expression and engagement of views and voices, issues and identities, and exhibits a complexity that has so far remained unexplored and under-theorized. This article outlines our conceptualization of 'communicative frames' and demonstrates its relevance in a systematic, comparative international analysis of terrestrial and satellite, public service and commercial television news produced and/or circulated in six different countries: the USA, UK, Australia, India, Singapore and South Africa. Recent developments in social theory, political theory and journalism studies all underpin our approach to how these frames contribute to meaningful public deliberation and understanding and, potentially, to processes of mediatized 'democratic deepening'. This article builds on these contemporary theoretical trajectories and develops a new approach for the empirical exploration and re-theorization of the fast-developing international ecology of TV journalism.
\end{abstract}

Keywords: communicative architecture; deliberative democracy; democratic deepening; display; news ecology; TV journalism.

\footnotetext{
* Artigo publicado na revista Media, Culture E Society, Vol. 28, No. 2, 163-189 (2006).

** Professor of Media and Communications in the School of Journalism, Media and Cultural Studies at Cardiff University [email: cottles@cardiff.ac.uk].

*** Principal research assistant at the University of Melbourne[email: m.rai@unimelb.edu.au].
} 
Television journalism is implicated in structures of dominance and processes of democracy. Recent developments have only exacerbated this Janus-faced relationship to the forces of conservatism and change. In today's globally interconnected, socially reflexive and culturally contending societies, the public representation and deliberation of issues, interests and identities has, if anything, become all the more necessary for the 'democratizing of democracies' (Giddens, 1994). In this article we argue that the naturalized, but hitherto theoretically invisible, communicative architecture of television news serves to display and deliberate conflict and consent in the contemporary world and, as such, potentially contributes to processes of democratic deepening. This communicative architecture also establishes the genre of television news as an internationally recognizable (perhaps now universal) 'way of knowing' for news producers, news audiences and news participants alike, practically organizing the production, communication and reception of 'news' (Corner, 1995; Dahlgren, 1995; Jensen, 1998). It exhibits, however, far more complexity than has so far been acknowledged. Setting an analytical course between the Scylla of political economy dynamics and the Charybdis of cultural studies' play of discourses, only a few studies have attended to the communicative and democratizing forms of journalism. To date, these include analyses of the micro-politics of news interviews (Clayman and Heritage, 2002), the unfolding dynamics of political scandals and mediatized public crises (Thompson, 2000; Cottle, 2004), the changing historical forms of news (Barnhurst and Nerone, 2001), and the accessing of ordinary people in discussion programmes and the deliberative engagements found within the arenas or 'agorae' of current affairs programmes Livingstone and Lunt, 1993; Cottle, 2002). But too often, it seems, a priori theoretical views about social dominance and the mechanisms of its enactment have contributed to the failure to empirically engage with the complexities of actual news programmes around the world, their communicative forms and deliberative possibilities. Whether conceived functionally in terms of an 'ideological state apparatus' (Althusser, 1971), politically as a 'propaganda model' (Herman and Chomsky, 1988), more discursively as a hegemonic site for the 'manufacturing of consent' (Hall, 1982) or perhaps 'governmentally' as a 'regime of truth' (Foucault, 1980), these and other influential theoretical optics tend to blind analysts to the complexities of journalism's communicative architecture as well as its democratizing possibilities. Simply put, there is more going on in the communication of news than the manipulation of news agendas by powerful strategic interests or the circulation of powerful semiotic codes and discourses.

The advent of digital and satellite technologies, multi-channel news operations, 24/7 real-time reporting, fragmenting audiences and the rise of populist news forms have all contributed to the unsettling of cosy 'family hearth' views of television news viewing. Today's television news ecology is both crowded and variegated. Public service and commercial news operations, terrestrial and satellite delivery systems, and forms of 'serious' and 'popular' news programmes all coexist and compete and do so at local, national, regional, international and global levels. It seems appropriate, then, to conceptualize television news in terms of 'formations', 'forms' and 'flows'. Heuristically these terms help to signal the corporate structuration and extending geo-political reach 
of television news production and circulation as well as its relational nature in terms of a symbiotic field of coexisting and competing cultural forms. What these formations, forms and flows have in common, however, is a shared 'communicative architecture' and it is this that forms the focal point of interest here.

Based on a study of the principal terrestrial and satellite, public service and commercial television news programmes broadcast in the USA, UK, Australia, India, Singapore and South Africa, this article examines how the communicative architecture of television news powerfully structures news dissemination. We analyse how this involves both analytic (propositional argumentative) and expressive (affective-aesthetic) dimensions of audience engagement and appeal, and how these dimensions structure news presentation in both conflictual and consensual ways. At the core of this communicative architecture we discern an established and conventionalized repertoire of communicative frames' that routinely organize how news events and issues are publicly communicated and contested. But this is to short-circuit the theoretical argument. Before we elaborate our conceptualization of television journalism's communicative architecture with supporting empirical findings, it is first useful to situate the study theoretically. Recent developments in social theory, political theory and media theory all underpin our conceptualization of how journalism contributes to meaningful public discourse and debate in contemporary liberal democracies, and how it could better serve processes of 'democratic deepening' in the future. We consider each briefly in turn.

\section{Social theory: globalization, reflexivity, cacophony}

Major contemporary social theorists collectively underline the need for the 'democratizing of democracy' (Giddens, 1994) when theorizing the expanded field of the subpolitical within civil societies and the cacophony of discourses and identities that processes of globalization, detraditionalization and increased social reflexivity have produced (Giddens, 1990, 1994; Beck et al., 1994; Beck, 1997, 2001; Castells, 1997).

Globalization, or 'the intensification of action at a distance', generates new forms of stratification, identities and conflicts (Giddens, 1994: 4-5). The revival of local nationalisms and an accentuating of local identities, for example, are often bound up with globalizing forces. In today's posttraditional social order 'traditions' are expected to defend themselves through reasoned dialogue or risk being seen as 'fundamentalist' and beyond rational engagement. Post-traditional, globalizing societies also produce increased social reflexivity where trust and deference towards social authorities and expert systems becomes increasingly undermined and where the production of 'manufactured uncertainties' or 'world risks' (Beck, 2001) generates environmental consciousness and 'ontological insecurities' (Giddens, 1990). Science and other codified knowledges are now likely to be internally contested, appropriated by lay people and subject to competing knowledge claims and social rationalities, and these can be visualized and dramatized in the media spotlight (Beck, 1992). Powerful states as well as individuals also encounter 'risks', of course, as the events of 11 September 2001 and its global aftermath bear witness (Zelizer and Allen, 2002). As the world's geo-political tectonic plates 
shift, so the legitimating arenas and public relations capabilities of the media become central in internationalized struggles for 'hearts and minds'.

Traditional solidarities of class and political allegiance rooted in the social relations of mass production have also become weakened by new flexible regimes of production and cultural patterns of consumption. And these too give rise to identity politics and new social movements that expand the field of 'the political' within civil society (Hall and Jacques, 1989; Mouffe, 1996; Beck, 1997; Castells, 1997), and they do so as the relative autonomy of nation states and traditional political allegiances decline. These profound social transformations, then, generate radical pluralism and a cacophony of interests and identities that prompt an expanded conceptualization of the liberal democratic polity (Cohen and Arato, 1994) and calls for the 'democratizing of democracy' (Giddens, 1994: 112-13). How these disparate fields of contention and transformation find expression in the prevailing forms of journalism, however, has yet to receive serious attention. The media, and television journalism in particular, we argue, constitute a central mediatized space for the public expression and elaboration of the contemporary forms of change, conflict and contention spawned by late modernity.

\section{Political theory: deliberation, display, democratic deepening}

Recent debates about deliberative democracy also sensitize us to the democratizing potential of television journalism. Political theorists of deliberative democracy have sought to carve out a theoretical space between 'liberal representative', 'civic republican' and 'participatory' models of democracy as a means of deepening forms of public engagement (Benhabib, 1996, 2002; Habermas, 1996; Dryzek, 2000). In summary terms, the ideas and ideals of deliberative democracy aim to overcome the evident 'democratic deficits' of extant liberal democracies, the essentialist and communitarian presuppositions of civic republican models, as well as the practical and logistical difficulties posed to direct or participatory forms of democracy by large-scale, complex societies. People talking in public, embodying differing interests and advancing contending arguments and discourses about the public good, are fundamental to processes of democracy. It is in the mediatized play of difference, for example, where ideas, identities and interests rub up against each other and are communicatively obliged to elaborate, justify and defend their claims and aims, that we, the watching and listening audience often find invaluable resources for improved understanding. Given its engagement with structures of domination, deliberative democracy should not, then, be seen as 'genteel conversation', but rather as a series of embattled fields of contention, insurgency and reflexivity that today are local to transnational in scope (Dryzek, 2000). Three important caveats need to be raised, however, in respect of current theoretical ideas about deliberative democracy.

First, definitions of deliberative democracy that are too closely tied to a central coordinating view of parliamentary processes, perhaps serviced through the 'sluice gates' of a public sphere conveying discourses of civil society upward to government and state institutions for action (Habermas, 1996), are too institutionally restricted. Deliberative processes, as suggested by contemporary social theory, can take place in diverse arenas 
and associations, inform inwards as well as extend outwards, move horizontally and culturally as well as vertically and politically.

Second, proceduralist views of deliberative democracy can also be questioned. Jürgen Habermas, for example, seeks to identify the grounds on which consensus can be reached and by which legitimate decision-making can be enacted. This, according to Habermas, can be arrived at on the basis of 'communicative reason'. Here the validity of statements and arguments are interrogated in relation to their claims to propositional truth, personal sincerity and normative rightness (Habermas, 1996: 5) and in this way 'the important function of social integration devolves on the illocutionary binding energies of a use of language oriented to reaching understanding' (1996: 8). This is an idealized and contexttranscending view of communication - an ideal-speech situation - that lends support to Habermas's wider social theory and its pursuit of a normative basis for social reconstruction, but this view of consensus-seeking 'communicative action' is a far cry from the reality of motivated interests and strategic action that informs most public discourse. Arguably, we need to develop a sharper sense of how processes of deliberation and the play of power enacted in communicative action are infused in practice (and are destined to remain so) and how these become conditioned and shaped when mediatized.

Third, ideas of deliberative democracy are apt to over-emphasize the power of reason and rationality at the expense of other powerful forms of communication. Ideas of deliberation need not always be modelled on, or confined to, legalistic and parliamentary fora and reasoned speech. Such rationalist pretensions often conceal the exclusive (and socially excluding) nature of many 'democratic' arenas. Iris Young makes the case, for example, that theorists of deliberative democracy must broaden their conception of the relevant forms and styles of communication and points to the importance of greetings, rhetoric and story-telling (Young, 1996). These variously sustain relations of care and trust, pull on desires and deepen mutual understanding of others through the communication of experiences and distinct cultural values and meanings.

Ideas of deliberative democracy, therefore, cannot be narrowly confined to extant political institutions, presume a proceduralist view of rationality, or work with a delimited understanding of reason - the radical pluralism of civil society and identified social forces of change militate against such consensual thinking. We can nonetheless concur that deliberative democracy requires a strong concept of the 'public sphere'. Seyla Benhabib defines this as 'mutually interlocking and overlapping networks and associations of deliberation, contestation and argumentation' (1996: 73-4). It is all the more remarkable, we think, that theorists of deliberative democracy, with the partial exception of Habermas $(1989,1996)$, have thus far failed to integrate analysis of media performance and potential into their own deliberations on deliberative democracy notwithstanding the media's constitutive role within contemporary mediatized civil societies.

\section{Journalism theory: public sphere(s), popular and public journalism}

Recent theorization of media in terms of 'public sphere(s)', popular journalism, and 'public journalism' also prompts a more historically nuanced, culturally differentiated 
and politically contested view of media performance and its democratizing potential. While critical rationalists and political economists generally lament the perceived erosion of the media public sphere and its capacity to marshal 'public knowledge' and address substantive 'issues', postmodernists and cultural studies theorists often redefine the 'political' in relation to the private sphere and celebrate media 'popular culture' and the play of 'identities'. Enlightenment and post-Enlightenment premises also surface in the study and evaluation of popular and tabloid forms of journalism (Curran et al., 1980; Dahlgren and Sparks, 1992; Hartley, 1996; Langer, 1998; Lumby, 1999; Sparks and Tulloch, 2000).

These debates register important shifts in both the worlds of television and its academic theorization, but neither orientation to our mind engages sufficiently with the complex forms of actually existing television journalism which evidentially straddle these and other deep-seated communication dualisms - whether conceived in terms of 'transmission' and 'ritual' models of communication (Carey, 1989), 'public knowledge' and 'popular culture' problematics of audience reception (Corner, 1991), 'objectivist' and 'subjectivist' news epistemologies (Cottle, 1993), 'narrative' and 'exposition' aesthetics in television news (Corner, 1995), or 'dialogue' and 'dissemination' approaches to communication more generally (Peters, 1999a). Such dualisms, we suggest, in practice interpenetrate in many of the complex forms of today's journalism and, indeed, in their applied specificity, help to define these as characteristic forms and grant them their appeal and communicative force. When seeking to understand how television journalism serves to summon publics in respect of events and issues, and does so in culturally expressive and affective ways as well as through informational and propositional means, less dichotomized thinking is clearly called for. We need to be able to accommodate and register the communicative modes of both display and deliberation within our analytical approach to current national and international formations of television news.

John Durham Peters reaches similar conclusions when discussing the worthy but ultimately idealist project of public journalism in the US (Glasser, 1999; Peters, 1999b; Rosen, 1999). Lending further weight to the necessity to reconsider journalism's communicative complexity, which encompasses both dialogue and dissemination, he suggests, 'Argument and deliberation have much to offer as modes of public debate. The question is their relative privilege in the rhetorical panoply of democracy' (Peters, 1999b: 111). And so it is. Informed by these preceding debates we now propose a new conceptual apparatus for mapping the complex communicative architecture of television news, its democratizing enactments and possibilities. This is then deployed in a comparative international examination of terrestrial and satellite television news.

\section{Researching TV news communicative architecture}

As well as being informed deductively by the debates above, our analytical schema of 'communicative frames' has also been developed inductively in a pilot study and now an extensive empirical study of news programmes broadcast in and across six different countries. Methodologically, our conceptualization of 'communicative frames' approxi- 
mates to 'ideal types' (Weber, 1949), that is, analytical categories designed to capture recurring and evident communicative structures of television news while nonetheless admitting to further levels of complexity in any particular case. That said, in their application we find that they demonstrate a grounded capacity to accurately capture the communicative structures of most television news items broadcast in all our selected countries and regions and do so with little or no interpretative difficulty.

At the centre of television journalism's communicative architecture are a number of 'communicative frames' routinely structuring the presentation and elaboration of news stories. These prove pragmatically useful in terms of the logistics, technical capabilities and pressurized organization of news production while nonetheless permitting some degree of journalist and organizational latitude in terms of how to construct both conflictual and consensual news stories. Moreover, in their enactment, journalists instantiate a number of professional claims concerning their responsibilities within processes of liberal democratic representation (Mill, 1811/1997, 1859/1997). These include, for example, providing information and social surveillance; demonstrating independence, balance and impartiality; acting as a critical watchdog; and facilitating public discussion, debate and opinion formation. The repertoire of communicative frames also permits much else besides, however, including: giving voice to the powerful; occluding or dissimulating dissent; constructing consensus; advocating and championing causes; expressing cultural differences; telling mythic tales; and bearing witness.

Our conceptualization of 'communicative frames', unlike conventional use of the term 'frames' in the news field (Gitlin, 1980; Gamson, 1989; Entman, 1993; Robinson, 2002: 137-40), is much more firmly anchored in the world of television news work and the professional ideology of journalism. Communicative frames pre-exist, we argue, the discursive constructions of any particular issue or news event. Conventionalized ideas about 'frames', however, are invariably discourse dependent and issue specific and, as such, insufficiently cognizant of the communicative structures that routinely make up television news and too quickly foreclose on the deliberative and open-ended possibilities that inhere within many of the 'communicative frames' comprising television news. These communicative complexities are simply lost from view by a reductionist understanding of news frames as necessarily involving a 'preferred point of view' or 'dominant discourse'. A typical definition, incorporating Robert Entman's (1993) ideas, states, for example, 'the concept of framing offers us a way to understand how information contained within any given text is mediated so as to privilege a particular reading of that text' (Robinson, 2002: 137). This widely held and discourse-dependent understanding of 'news frames', we suggest, too easily slides over the formal complexities of the communicative architecture of television news. Recent studies of television reception seem to lend support to our view when finding that audiences are in fact complexly involved in reading processes, and often discriminating and, effectively, 'deliberating' in their evaluations and judgements about journalism topics, their evidential basis and civic forms of presentation (Corner et al., 1990; Jensen, 1998; Buckingham, 2000). 


\section{Television news and its repertoire of communicative frames}

Contemporary television journalism is oriented to the world in both conflictual and consensual ways, and this is embedded within its communicative architecture (see Figure 1).

Television news routinely deploys a number of recurring, possibly universal, conflict communicative frames. Our research reveals that these can be differentiated analytically as 'dominant', 'contest', 'contention', 'campaigning' and 'exposélinvestigative'. While each structures the communication of conflicts in different ways, each nonetheless communicates principally in terms of contending claims, propositions and arguments. Conflicts thereby assume propositional and analytical form and these resources become available for public deliberation. Not all news is about conflicts and framed in analytical terms, however. A number of consensual frames, based more on cultural display than analytical dissemination also characterize television news and this is communicated, we argue, through the following cultural communicative frames: 'community service', 'collective interests', 'cultural recognition' and 'mythic tales'. While the content of some of these news presentations may at times be premised on hidden or perhaps structural conflicts, the communicative frame nonetheless positions them consensually with no obvious issue or contending perspective in play. These consensual communicative frames, unlike the conflict-driven and analytical frames, exhibit varying degrees of cultural depth, moving from the semiotic to the symbolic and mythic, and thereby 'display' (rather than 'deliberate') in keeping with their more culturally expressive mode of communication. Their essence and appeal lies in the communication of cultural interests and identities, in recognition and display, rather than in the representation of conflict communicated analytically or argumentatively. Finally, two powerful news frames, 'reporting' and 'report-

Figure 1:

TV journalism's communicative frames

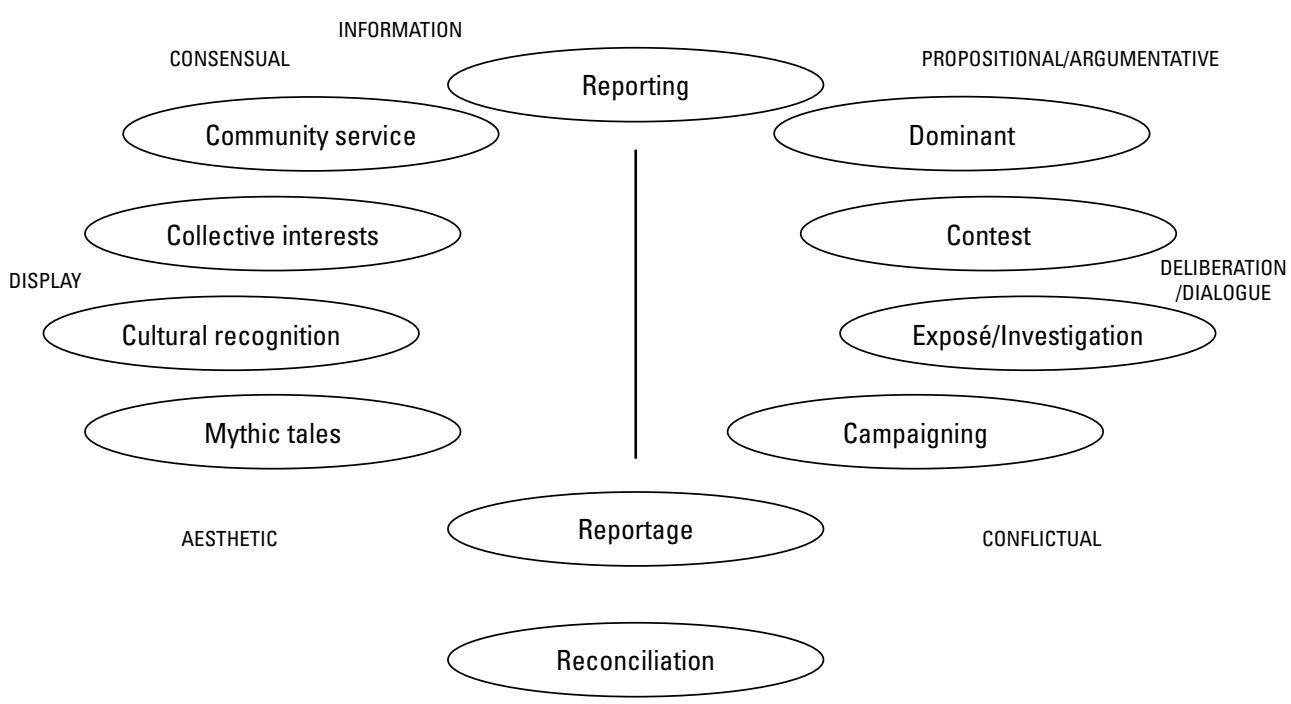


age', draw upon both analytic/propositional and aesthetic/ expressive, or deliberative and display modes of communication, as does the rarely deployed depth frame of 'reconciliation'. We can now briefly describe each frame with an illustration drawn from our international sample before we examine to what extent each is deployed within and across our six countries and major satellite broadcasters.

\section{Reporting}

At the core of the historical evolution of television news is the 'classic' reporting frame. This instantly recognizable frame functions principally in terms of information conveyance and the surveillance of current events consonant to the daily production cycles of television news (Halloran et al., 1970; Wright, 1974). The events reported on can be conflictual or consensual in nature, but they are framed by the news presentation in terms of up-to-date information and are generally, though not always, of short duration. They serve, nonetheless, to ground journalism's professional mission 'to inform' as well as lend some factual support to ideas about accuracy and even objectivity, but deliver at best thin accounts of events, which are often presented as occurrences without context, background or competing definitions and accounts. They provide basic informational elements that may later or elsewhere inform more elaborate interpretations, discursive and emotional alignments and evaluative judgements of these same events.Bangladesh is mopping up after the heaviest rainstorms in more than half a century. Much of the country, including the capital Dhaka, is under several feet of water. More rain is expected over the next few days. (BBC1 News, BBC1, UK, 15 September 2004)

\section{Dominant}

Closely aligned to, but deliberatively developing beyond the news controlled reporting frame, is the dominant frame. This frame refers to news stories that are clearly dominated and defined by a single external news source. This source may derive from authority, challenger or any groups within the social hierarchy, but it is their perspective or views which clearly 'dominate' the communicative frame and which either remain unopposed or receive, at most, marginal challenge. When the latter, challenges are typically confined to responses that are prefigured by the agenda set by the dominant 'framing' source. This frame, then, comes closest to the classic view of 'primary definition' as elaborated by Stuart Hall and his colleagues (Hall et al., 1978). It need not, however, in principal be taken to be dominated by social elites, though in practice it may often be.

Manpower Minister Ng Eng Hen says the move to keep civil service manpower numbers in check is a prudent one. Even at a time where the economy is picking up and retrenchment numbers are coming down.

Minister Ng: This isn't just an exercise in manpower reduction - that's not the aim of it. This is an exercise in making sure that we are as accountable and as efficient for government. In other words, we must seek to be efficient and lean because this is taxpayers' money. It doesn't mean that we will just reduce manpower because we have to reduce it. ... (Channel $i$ News, Channel i, Singapore, 19 September 2004). 


\section{Contest}

Television news also presents news stories in terms of a contest frame. Here conflictual news stories are framed in terms of binary opposition, with opposing views and arguments generally given approximately equal weight or representation and structured in adversarial terms and formats. While comment and criticism may also be delivered on these 'contests' by accessed experts or 'arbitrators' (Deacon and Golding, 1994), the frame nonetheless presents the conflict in terms of a fundamental opposition between two opposing sides or interests and these are clearly signalled and structure the communicative frame.

Now to the presidential race and the war in Iraq continues to be the top campaign issue. Senator Kerry today launched a sharp attack against President Bush, saying the war in Iraq is undermining the war on terror. The President, meanwhile, is firing back.

Reporter: In the swing state of Wisconsin today, the President fired back at Senator Kerry, accusing him of undercutting an ally, the interim leader of Iraq.

President Bush: You can't lead this country if your ally in Iraq feels like you question his credibility. The message ought to be to the Iraqi people 'We support you'. The message ought to be loud and clear.

Reporter: Earlier today, Senator Kerry in Pennsylvania, ripped President Bush saying he bears responsibility for letting Osama bin Laden get away.

Senator Kerry: The President outsourced the job to Afghan warlords who let Osama bin Laden slip away. That was the wrong choice. Instead of finishing the job in Afghanistan, the President rushed into a new war in Iraq. That was the wrong choice. (CBS Evening News, CBS, USA, 24 September 2004)

\section{Contention}

Further conflictual complexity is encapsulated within the television news contention frame. Here a plurality of voices/perspectives may be represented and these do not take the form of a diametric opposition, but rather represent something of the complexity of positions and points of view that often inhere within and/or surround particular areas of contention or dispute. The contention frame is not confined to the elaboration of conflictual currents that circulate within or around deep oppositions and 'contests' but also serves to capture the more nuanced and qualifying engagements of different interests and identities which variously debate, criticize or contend, but which do not fundamentally challenge or oppose some state of affairs, interest or perspective.

Reporter: ... in overwhelmingly Muslim Turkey, paradoxes abound ... marriage is only official here if it's a state marriage. And the state is now poised to involve itself further in married life. The Turkish government seems surprised by the outcry over its proposal to criminalize adultery. The proposal divides Turkey, coming down to the way you view the world.

Selen Akcali works as a consultant. She is the epitome of the westernized Turkish citizen. Mutlu Alkan defies every stereotype - a successful businesswoman, a devout Muslim, a rising official in the governing AK party and a pretty neat driver. 
Selen's view of the state is thoroughly European. Regulating the traffic is fine, but her private life should remain just that - private.

Reporter: But Mutlu, in spite of her entrepreneurial drive, sees a role for the government in helping women less able to help themselves than she is.

Mutlu Alkan: ... there is a need for this because they [women] cannot do much about their husbands ... this will just show them that they have a support behind. If they complain, yes, the state is with them.

Reporter: ... There's little doubt amongst most observers that it is the AK government that has brought Turkey tantalizingly close to EU membership negotiations ... which makes the adultery law doubly bizarre. As the storm over the adultery proposal grew, the government tried legal defenses.

Nimet Cubukcu, MP, AK Party: It is the European Court of Human Rights that makes the legal structure of the European Union. And the court says that every country can regulate its laws according to its social and moral requirements ...

Professor Haluk Sabin: Turkey has very obstinate opponents in Europe, you know some people who believe that Turkey just does not fit in the European scheme of things, have been looking for reasons and excuses. ... And now they will have another thing to chew on ...

Reporter: As the debate on the penal code began on Tuesday, women's rights groups protested on the capital's streets. ... But ... there is a sizable group of people here, religious and conservative, who support the criminalization proposal - the world beyond metropolitan Istanbul.

...

Rubiye Akcam: I am against withdrawing such a law. We are Turkish, we are Muslim, and if you do such a thing as adultery, you should bear with the consequences, and you should be punished.

Reporter: Without government support the adultery proposal will probably fail, but the EU has been put on notice. Turkey is different. Not just because it's Muslim or conservative, but because of the contradictions embedded deep within the republic. Secular and religious, traditionalist and urgently modern, east and west at once. (Newsnight, BBC2, UK, 16 September 2004)

\section{Exposé/investigation}

This frame, like the classic news reporting frame, remains under the firm control of the news media but is also actively driven forward. The exposélinvestigation frame conforms to the idealized liberal democratic role of journalism as public watchdog and as self-proclaimed Fourth Estate. Here journalists actively set out to investigate, expose and uncover information and practices that would not otherwise be revealed within the public domain. This frame includes, therefore, traditional investigative journalism based on intensive research and exploratory fact-finding as well as exposé journalism of public or private affairs.

But first, our water, and just how safe is it? Tonight we expose one of Australia's largest companies using the cover of darkness to pump waste into one of the country's major river systems. It's happening night after night and wait till you see what the company did when it found out about our investigation. 
[undercover night camera footage of a man feeding hoses into a river]

Reporter: What is this man doing? A construction worker under the cover of darkness throwing hoses containing contaminated water into one of Australia's major river systems. What's being pumped out here is by-product from one of the country's largest construction sites by workers from one of the country's largest companies, Thiess Hochtief.

Anonymous source with face obscured and voice altered: They're well aware that they are polluting that river with chemicals. If you've gotta start hiding things at night, you've gotta start scratching your head and thinking 'Well, what's going on here?'

[footage of hoses pumping contaminated water into a river]

...

Reporter: This man should know - he was one of the so-called 'water boys' until he came to us, worried his company was polluting the river. ... And it's not just any river. It's the Lane Cove National Park ... Reporter: But exactly what is Thiess Hochtief dumping? With the help of a second worker we took samples from the building site to determine exactly what was being discharged.

$\cdots$

Reporter: ... Our test results show the water is acidic and should have hydroxide added before pumping back into the river.

Reporter: ... The EPA [Environment Protection Authority] is now looking into that site and admits it is investigating the company over two other environmental issues. (Today Tonight, Channel 7, Australia, 13 September 2004)

\section{Campaigning}

Television news journalism also has the capacity to actively and performatively campaign for particular causes and issues though, unlike the press, it may rarely elect to do so. This constitutes the campaigning frame. Here the news media declares its stance on a particular issue or cause and seeks to galvanize sympathies and support for its intervention beyond the world of journalism. Accessed views and voices are often demonstrably positioned to bolster or strengthen the media's case in challenging, opposing or proposing a particular perspective and course of action.

Five News has been given horrific video footage recorded during an undercover investigation in Pakistan into animal cruelty. Wildlife investigators have been telling our reporter Mark Jordan how bears have their teeth broken and their claws removed. The animals are chained so their movement is restricted and fighting dogs are let loose on them. The law says bear baiting is illegal in Pakistan, but it's still happening. A word of warning some of you may find parts of this report distressing.

[visuals of men buying tickets to a bear-baiting event]

Reporter voice-over: How much pain could a man witness for just a few pennies? In Pakistan, you get plenty for your money ...

[footage of two men dragging a bear into the ring, with another man hitting the bear with a stick]

Reporter: They are only animals, but try arguing that this bear doesn't know what's about to happen to him. Dragged to the ring, this should not be happening. Campaigners persua- 
ded Pakistan to make it illegal, but few here care about that law, a recent event was actually organized by a wildlife officer.

...

Reporter voice-over: Pakistan may have plenty to worry about, what with the war on terror, but to many, this is terror, and the victim is innocent. (Five News, Channel 5, UK, 17 September 2004)

\section{Community service}

Moving beyond the classic news reporting frame, by going a little deeper into a particular issue or event in terms of what new 'information' actually means for the news audience is the community service frame. Through this communicative frame the news media explicitly advise the audience on what this information actually means and how it impacts on them. Here, then, the news media takes on a more advisory or service-oriented role. Information that is essentially consensual (as opposed to conflictual, which would suggest a media-led exposé/investigative frame) is represented as useful or essential advice and may be presented in a pedagogic and/or paternalist way. In today's news ecology, the latter may variously address or seek to 'interpellate' audiences in terms of citizenship or consumption.

Now for more on tomorrow's strike, we are joined by e news reporter Lindelwa Mthembu. Lyndie, what sort of disruptions can we expect in Johannesburg tomorrow?

Reporter: ... Looking at the routes in Pretoria - that's where the biggest march will be - we are expecting about 50,000 people to be in Pretoria. ... Avoid Church Square route, avoid the vicinity of the union building. They will be using Paul Kruger going towards the union buildings, after they've handed the memorandum to national treasury. Also avoid Hamilton Street because two lanes will be closed to accommodate for the buses that will be transporting the marchers. About 80 buses, so you can imagine the big impact that will be expected. ... (News@7, eTV, South Africa, 15 September 2004)

\section{Collective interests}

Like the community service frame, the collective interests frame structures its representation consensually. Here, however, news stories do not simply report on news events or provide advice, but rather elaborate and visualize shared, communal or collective interests through their identification of presumed 'common interest' subject matter. This communicative frame serves to embody values and ideals of presumed shared interest and collective relevance and appreciation.

Gates have opened at the Royal Melbourne Show and crowds have wasted no time in checking out the attractions. And with most schools starting holidays tomorrow, organizers are hoping for a bumper week ahead. More from Mia Greeves.

[visuals of horses with their owners at the competition]

Reporter: Animal judging began before the gates opened and Yambula Chief, and owner, Victorian police chief Christine Nixon, made their debut ...

[visuals of cakes on display] 
Reporter: And after eight years of competitive baking, Peter Bennett from South Yarra has finally taken the silver spoon for overall cooking.

Peter Bennett: I'm absolutely over the moon. I didn't think that I would ever be able to do it!

[visuals of excited children lining up for showbags]

Reporter: And one of the show's longest running showbags has again proved its popularity.

[visuals of children and families pouring into gates with reporter voice-over]

Reporter: Despite the prediction of rain over the weekend, organizers are expecting half a million people to come through the gates over the next eleven days. (Nine News, Channel 9, Australia, 16 September 2004)

\section{Cultural recognition}

The cultural recognition frame refers to consensual items that not only represent, but also symbolize and/or affirm shared values and community ideals - whether 'Ours' or 'Others'. This frame of 'recognition' (Taylor, 1995) serves to evoke and appeal to notions of cultural identity and cultures of difference (West, 1993; Young, 1997) by, inter alia, acknowledging and/or celebrating events/individuals/groups represented. This consensual frame, then, can variously be deployed to display and endorse views of multicultural difference (very broadly conceived) and/or implicitly reassert monocultural conceptions of cultural homogeneity, though neither will be framed in conflictual terms (see Hannerz, 2000).

Happy is the bride that the sun shines on, the phrase goes. But that is not the only reason an American woman and an Australian man decided to exchange vows at this exotic destination in Malaysia. RTM invites us to witness this special day in their lives.

[visuals of pristine beaches and native dancers with reporter voice-over]

Reporter: Serenity and tranquillity are the Carey Island, and the simple lifestyle of the indigenous people of Malaysia, the Mahmeri community, have always fascinated Gloria Grace Wallace from the United States. It is no wonder when she and Mark Anthony from Australia decided to tie the knot, they wanted to perform it according to the Mahmeri culture.

[visuals of the bride and groom performing several traditional rituals, with an indigenous elder]

The big day began with the engagement and the exchange of rings to symbolize their union. The chieftain of the Mahmeri community, the medicine man and the couple's parents play a major role in the ceremony.

$\cdots$

[visuals of wedding procession with bride and groom in traditional Mahmeri attire]

Dressed in simple attire decorated with intricate woven coconut leaves, Gloria Grace is led in a procession to the house where they will be wedded. The bersamin ceremony or sitting on the dais must be performed before noon or bad luck will befall on the ceremony. The couple are blessed by their parents and close relatives.

[visuals of the couple celebrating with the Mahmeri community] 
For Gloria and Mark their wedding ceremony, though simple, will always be cherished and remind them of their wonderful stay here in Carey Island.

Groom: Their excitement and their willingness to share and to have fun. The whole thing's also interwoven with, as I've found out today, all sorts of symbolic rituals that have got a really deep meaning.

Bride: The Orang Asli Community, the Mahmeri of Carey Island, we love Carey, because they made today, our wedding, very, very special. (World Report, CNNI, Satellite TV, 26 September 2004)

\section{Mythic tales}

The mythic tales frame displays and activates cultural myths that have resonance for contemporary cultures. This communicative frame, then, is not principally about imparting new information but resurrecting and/or recycling pre-existent values, symbols and narratives which draw from the deep cultural/collective myths that exist within all communities (Bird and Dardenne, 1988). These mythic tales may focus on individuals/groups/ places/objects that symbolize values or ideals that are exceptional or extraordinary in some way and/or which are felt to be normative cultural 'goods'.

South Africans said farewell today to one of the heroes of their struggle for freedom. Antiapartheid cleric Beyers Naude died two weeks ago at his Johannesburg home. ...

[moving visuals of funeral procession and mourners in the church with reporter voiceover]

Reporter: They came to pay tribute to a fallen hero, a soldier of the struggle, who will fight no more. And for Beyers Naude it was a fight that was not without casualties. He was ostracized from his church and his community because of his beliefs, but he was adopted by a nation.

[visuals of African gospel choir singing at the funeral]

Reporter: An Afrikaan who was ideally placed to live a life of entitlement under apartheid, but this was not to be for Naude. ... Beyers Naude's ashes are to be scattered in Alexandra township, a community he spent most of his life serving.

Reporter to camera: It was the funeral here at the Aswen Corp Dutch Reform Church, a full circle has been completed. It was here in 1963 that Beyers Naude left the ministry because he was opposed to his church's support of apartheid.

Today South Africans of all races returned to farewell and pay tribute to Beyers. (News@7, eTV, South Africa, 18 September 2004)

\section{Reportage}

A communicative frame that goes well beyond the simple informational and surveillance ambitions of the reporting frame in its attempt to generate deeper understanding and insights into current news events is the reportage frame. The reportage frame seeks to do this through the provision of detailed background, context and analysis; in situ observation, first-hand testimony and/or experiential accounts of events; or journalist reflexivity in respect of earlier media reporting. The reportage frame can, therefore, represent issues and events either in conflictual or consensual terms, and can also variously deport itself by emphasizing either display/expressive or deliberative/analytic 
modes of representation, but in either case it aims to provide the means for generating in-depth understanding by going behind the scenes of 'thin' news reports and providing 'thick' descriptions of reality (Geertz, 1973; Cottle, 2005). The reportage frame, given its affinity with observational documentary modes (Nichols, 1991), invariably makes use of film and visual authentication as well as personal testimonies, and thereby often positions itself (and us the viewer) as 'bearing witness'. Reportage often 'moves' (performatively, diachronically and emotionally) from the indicative to the subjunctive in its story treatment (Cottle, 2004, forthcoming a).

Amid the daily reports of violence and death in Iraq, there are other tragic stories that don't make the headlines. Diana Muriel reports on the day-to-day struggle a group of Iraqis endures in Baghdad.

Reporter: Down an anonymous backstreet in Baghdad's Kadamir district is a boarding house that is home to a small army - a small army of beggars. A series of one-room hovels, 150 people crammed in together.

[visuals of children playing in dilapidated slum area and washing dishes with dirty water, reporter voice-over]

Reporter: With just one communal tap and one latrine, the stench is overwhelming. There weren't many people around the day we visited, most of the inhabitants out working. Each day a Dickensian Fagin figure, who runs this establishment and several others like it, collects the children and puts them to work begging in the streets. Each child must earn the equivalent of $\$ 3.50$ a day. For that, they and their families get living space. But not all the children here are with their parents.

[visuals of young woman surrounded by several children with reporter voiceover]

Reporter: This woman, who was too frightened to give her name and age, says she and her husband found seven kids in the street. They bring in just enough for rent and food, she says. She has two sons of her own, but barely enough food to give them. She herself grew up in this compound after being picked up off the street ... Once inside, there is almost no way out. People here live in fear of the man who runs their lives. Only a few of the prettiest young girls can escape. This one, too frightened to show her face to the camera, has been sold to a man she has never met in Syria. She knows she is destined to be a prostitute. She is just happy to be leaving.

[visuals of elderly woman sobbing and her husband crying with reporter voiceover]

Reporter: The oldest members of the community are perhaps the most pitiful. 'We have nothing', wails this woman. Tears run down her husband's face as he explains how he has suffered a stroke and she was forced to go out into the streets to beg ...

[visuals of mosque with reporter voice-over]

Reporter: This is one of the most profitable places to beg in Baghdad, outside the mosques. And it's here the beggars congregate. But even so, there are few pickings and little pity for some of the city's most desperate. (CNN World News, CNNI, Satellite TV, 18 September 2004)

\section{Reconciliation}

One final television news frame, rarely used, has the capacity to go even deeper than in-depth reportage. Potentially at least, it can encompass and extend beyond the performative community service and campaigning frames, to structure its representations in 
terms of 'reconciliation'. Here the broadcasters can become actively involved in bringing opposing or conflicted interests and identities together, enhancing understanding and trust in respect of past or present enmities. Based on powerful modes of public display as well as engaged dialogue, such a communicative frame is likely to appeal to proponents of 'public journalism' and 'peace journalism' (Rosen, 1999; Lynch and McGoldrick, 2005). Building on filmic modes of reportage and deliberative televisual forums, as well as news technologies (satellite link-ups, internet discussion rooms, live telephone polls) the news media here performatively champion processes of reconciliation or 'coming together' - both literally through their presentational configuration of bodies in mediatized space and also figuratively (Cottle, 2002, 2005). Though we can recall examples from our own news viewing, none were present in our sample.

\section{Communicative frames: a universal TV news architecture?}

Systematically and carefully examining 9662 news items produced by our extensive sample of national and satellite TV news broadcast across our six selected countries generates the following findings (see Table 1).

As anticipated perhaps, the reporting frame is far and away the most commonly used communicative frame across both terrestrial and satellite news programmes (59.4 percent), suggesting a continuing organizational and professional commitment to the informational and event-oriented role of television news journalism (as well as, perhaps, organizational reliance on news agencies and considerations of news production costs). Interestingly, the use of this standard reporting frame also varies across national contexts, with a high of 60.6 percent in Australia and a low of 52.7 percent in the UK, and a high of 66.3 percent in the satellite broadcasters' output. Even so, there is much else going on in the communicative architecture of television news. Dominant frames, whether advanced by authority or challenger groups, are the next most prominent communicative frame (12.0 percent). Contest and contention frames together (11.6 percent) indicate that conflict reporting is often structured in terms of varying degrees of complexity and that protagonists find routine public representation and possible access for the engagement and elaboration of opposing views.

Excepting the traditional news reporting frame (which reports both conflict and nonconflict events), conflictual frames comprise almost a quarter of all the communicative frames deployed across the national and international contexts, though these also vary considerably in their national use: the UK (30.3 percent) and India (29.1 percent) with the most, and Singapore (21.0 percent) and the satellite broadcasters ( 20.2 percent) with the least (and, in Singapore's case, significantly, over 80 percent of these occur in items on foreign news). Consensual frames are in fairly infrequent use in most news contexts (13.9 percent overall), with the exception again of Singapore where they number 22.4 percent - the only country where they outnumber the use of conflictual frames. Exposélinvestigative and depth reportage frames are both relatively infrequent, though interestingly satellite TV and US broadcasters make appreciable use of the latter. But, we need to remember that frequency is not always the same thing as significance, and 'depth' reportage 
frames now routinely feature within and across many news outlets and elaborate their stories at length, often making use of powerful modes of display and deliberation.

\section{Conclusions}

It is evident from our study that television news exhibits a communicative complexity that so far has received, at most, partial recognition in the field of journalism study. Each country and satellite network in our sample has used most, if not all, of the identified communicative frames. These are, we suggest, universal structures organizing the formations of television news within liberal democracies. Together they constitute a differentiated communicative architecture for the deliberation and display of conflict and consent.

Of principal interest, perhaps, are the documented differences in the use of communicative frames between the national contexts. For example, the high use of conflictual frames in a volatile democracy such as India compared to the high use of consensual frames in a soft-authoritarian state such as Singapore. If consensual communicative frames in Singapore serve processes of 'manufacturing of consent', they often do so without directly articulating dominant views or necessarily accessing elite 'primary definers' - a view that is too often occluded in debates about the appeals of popular journalism conducted elsewhere. But so too can communicative frames serve processes of democratic deliberation through the public elaboration and engagement of contending interests and identities. Though in a minority, the deployment of in-depth frames of reportage and exposélinvestigation in liberal democratic states can contribute vital resources for processes of democratic deepening. These 'ways of knowing' (analytical, evidential, dialogic, experiential, testimonial, reflexive) variously give expression to identities of difference and processes of change, and can provide rich communicative means for their public elaboration. Frames of cultural recognition and even, on occasion, mythic tales also have their place within the scheme of television news, and these too, on occasion, can play a part in deepening cultural sensibilities and understanding (as could, potentially, the socially cathartic 'reconciliation' frame).

While each of these communicative frames has an established presence within the national and international communicative repertoire of television news, they are also found to varying degrees in and across national and international broadcasting contexts. The range and diversity of communicative frames deployed in each case are relatively broad and these are not, by definition, essentially issue specific - though some news events or issues may well be seen by news producers as lending themselves to certain communicative frames rather than others. We therefore resist the temptation to draw evaluative or judgemental conclusions that simply suggest one frame is intrinsically or necessarily 'better' than any other.Each has its possible advantages and benefits, as well as possible limitations, and each contributes something to the distinctive appeals and communicative architecture of different news forms. How they are selected and deployed in combination, however, and with what discursive consequences in the mediatization and elaboration of different issues and interests, now needs critical exploration. 
What this study has demonstrated is that a complex communicative architecture structures the daily outpouring of television news broadcast to millions of people around the world, and at the centre of this is a repertoire of identifiable communicative frames offering differing possibilities for the public elaboration and engagement of contending interests, issues and identities. More critically, we suggest, it is in and through their professional selection, enactment and combination that mediatized 'democracy' or 'dominance' variously wins out. Our continuing research seeks to integrate analysis of the identified communicative frames in relation to: (1) different news forms and news formations in different national and international contexts; (2) the changing nature of current affairs and documentary modes of television journalism; (3) their professional enactment in different production domains and environments; (4) their facilitation by technical inputs (ENG/video, edited interview clips, live studio interviews, group discussion, satellite link-ups etc); (5) their circulation via international flows and the syndication of news stories between broadcasters and regions; and (6), perhaps most importantly, their impact on the mediatization of major global issues, including ecology, the 'war on terror', population flows, indigenous and minority representation, and human rights.

This article has laid a foundation stone for this more extensive research programme. Here we have lifted the theoretical veil usually concealing the communicative complexities of television news and glimpsed something of the democratizing possibilities that inhere within the communicative frames now routinely deployed within and across national and international news formations. The communicative architecture of television news, we conclude, is implicated in both structures of dominance and processes of deliberative democracy. If deliberation is the soul of democracy, the communicative frames of television news can contribute to its mediatized enactment as well as its possible future deepening. This demands closer interrogation.

\section{Notes}

1. We would like to acknowledge the Australian Research Council for funding the research project 'Television Journalism and Deliberative Democracy: A Comparative International Study of Communicative Architecture and Democratic Deepening' (DP0449505) that forms the basis of this article and a number of forthcoming publications (Cottle, forthcoming; Cottle and Rai, forthcoming; Rai and Cottle, forthcoming).

2. Daily news programmes were selected on grounds of state broadcaster and highest commercial ratings. Other TV journalism formats including, for example, weekly current affairs and documentaries were excluded for the purposes of this article, but are included in research currently under way.

\section{References}

Althusser, L. (1971) 'Ideology and Ideological State Apparatuses', in Lenin and Philosophy and other Essays. New York: Monthly Review Press.

Barnhurst, K.G. and J. Nerone (2001) The Form of News: A History. New York: Guildford Press.

Beck, U. (1992) Risk Society. London: Sage. 
Beck, U. (1997) The Reinvention of Politics. Cambridge: Polity.

Beck, U. (2001) World Risk Society. Cambridge: Polity Press.

Beck, U., A. Giddens and S. Lash (eds.) (1994) Reflexive Modernization. Cambridge: Polity Press.

Benhabib, S. (ed.) (1996) Democracy and Difference. Princeton, NJ: Princeton University Press.

Benhabib, S. (2002) The Claims of Culture. Princeton, NJ: Princeton University Press.

Bird, E. and R.W. Dardenne (1988) 'Myth, Chronicle and Story: Exploring the Narrative Qualities of News', pp. 67-86 in J. Carey (ed.) Media, Myths and Narrative. London: Sage.

Buckingham, D. (2000) The Making of Citizens. London: Routledge.

Carey, J. (1989) Communication as Culture. London: Unwin Hyman.

Castells, M. (1997) The Information Age, 3 vols. Cambridge: Blackwell.

Clayman, S. E. and J. Heritage (2002) The News Interview. Cambridge: Cambridge University Press.

Cohen, J. and A. Arato (1994) Civil Society and Political Theory. Cambridge, MA: MIT Press.

Corner, J. (1991) 'Meaning, Genre and Context: The Problematics of "Public Knowledge" in the New Audience Studies', pp. 267-84 in J. Curran and M. Gurevitch (eds.) Mass Media and Society, 1st edn. London: Edward Arnold.

Corner, J. (1995) Television Form and Public Address. London: Edward Arnold.

Corner, J., K. Richardson and N. Fenton (1990) Nuclear Reactions. London: John Libbey.

Cottle, S. (1993) TV News, Urban Conflicts and the Inner City. Leicester: Leicester University Press.

Cottle, S. (2002) 'TV Agora and Agoraphobia Post-September 11', pp. 178-98 in B. Zelizer and S. Allan (eds.) Journalism after September 11. London: Routledge.

Cottle, S. (2004) The Racist Murder of Stephen Lawrence: Media Performance and Public Transformation. Westport, CT: Praeger Publishers.

Cottle, S. (2005) 'In Defence of “Thick” Journalism', pp. 109-24 in S. Allan (Ed.) Journalism: Critical Issues. Maidenhead: Open University Press.

Cottle, S. (forthcoming a) Mediatized Conflict: Developments in Media and Conflict Studies. Maidenhead: Open University Press.

Cottle, S. (forthcoming b) 'Mediatizing the Global War on Terror: Television's Public Eye' in P. Anandam Kavoori and T. Fraley (eds-) Media, Terrorism and Theory: A Reader. Oxford: Rowman and Littlefield.

Cottle, S. and M. Rai (forthcoming) '24/7 Revisited: Emissaries of Global Dominance or Global Public Sphere?'

Curran, J., A. Douglas and G. Whannel (1980) 'The Political Economy of the Human Interest Story', in A. Smith (ed.) Newspapers and Democracy. Cambridge, MA: MIT Press.

Dahlgren, P. (1995) Television and the Public Sphere. London: Sage.

Dahlgren, P. and C. Sparks (1992) Journalism and Popular Culture. London: Sage.

Deacon, D. and P. Golding (1994) Taxation and Representation. London: John Libbey.

Dryzek, J. (2000) Deliberative Democracy and Beyond. Oxford: Oxford University Press.

Entman, R. (1993) 'Framing: Toward Clarification of a Fractured Paradigm', Journal of Communication 43(4): 51-8.

Foucault, M. (1980) Power/Knowledge. London: Harvester Press.

Gamson, W. A. (1989) 'News as Framing', American Behavioral Scientist 33: 157-61.

Geertz, C. (1973) The Interpretation of Cultures. New York: Basic Books.

Giddens, A. (1990) The Consequences of Modernity. Cambridge: Polity Press.

Giddens, A. (1994) Beyond Left and Right. Cambridge: Polity Press.

Gitlin, T. (1980) The Whole World is Watching. Berkeley: University of California Press.

Glasser, T. (ed.) (1999) The Idea of Public Journalism. New York: Guildford Press.

Habermas, J. (1989) The Structural Transformation of the Public Sphere. Cambridge: Polity Press.

Habermas, J. (1996) Between Facts and Norms. Cambridge: Polity Press.

Hall, S. (1982) 'The Rediscovery of Ideology: Return of the Repressed in Media Studies', pp. 56-90 in M. Gurevitch, T. Bennett, J. Curran and J. Woollacott (eds.) Culture, Society, Media. London: Methuen.

Hall, S., C. Critcher, T. Jefferson, J. Clarke and B. Roberts (1978) Policing the Crisis. London: Macmillan.

Hall, S. and M. Jacques (eds.) (1989) New Times. London: Lawrence and Wishart.

Halloran, J.D., P. Elliott and G. Murdock (1970) Demonstrations and Communication. Harmondsworth: Penguin.

Hannerz, U. (2000) Foreign News: Exploring the World of Foreign Correspondents. Chicago: and London: University of Chicago Press.

Hartley, J. (1996) Popular Reality: Journalism, Modernity, Popular Culture. London: Arnold.

Herman, E. and N. Chomsky (1988) Manufacturing Consent. New York: Pantheon. 
Jensen, K.B. (ed.) (1998) News of the World: World Cultures Look at Television News. London: Routledge. Langer, J. (1998) Tabloid Television. London: Routledge.

Livingstone, S. and P. Lunt (1993) Talk on Television. London: Routledge.

Lumby, C. (1999) Gotcha: Life in a Tabloid World. St Leonards, NSW: Allen and Unwin.

Lynch, J. and A. McGoldrick (2005) Peace Journalism. Stroud: Hawthorn Press.

Mill, J. (1811/1997) 'Liberty of the Press', pp. 16-21 in M. Bromley and T. O’Malley (eds.) A Journalism Reader. London: Routledge.

Mill, J.S. (1859/1997) 'Of the Liberty of Thought and Discussion', pp. 22-7 in M. Bromley and T. O’Malley (eds.) A Journalism Reader. London: Routledge.

Mouffe, C. (1996) 'Democracy, Power and the "Political", pp. 245-56 in S. Benhabib (ed.) Democracy and Difference. Princeton, NJ: Princeton University Press.

Nichols, B. (1991) Representing Reality: Issues and Concepts in Documentary. Bloomington: Indiana University Press.

Peters, J. D. (1999a) Speaking into the Air. Chicago: University of Chicago Press.

Peters, J. D. (1999b) 'Public Journalism and Democratic Theory: Four Challenges', pp. 99-117 in T. Glasser (ed.) The Idea of Public Journalism. New York: Guildford Press.

Rai, M. and S. Cottle (forthcoming) 'Global Mediations: On the Changing Ecology of Satellite Television News', Robinson, P. (2002) The CNN Effect. London: Routledge.

Rosen, J. (1999) 'The Action of the Idea: Public Journalism in Built Form', pp. 3-20 in T. Glasser (ed.) The Idea of Public Journalism. New York: Guildford Press.

Sparks, C. and J. Tulloch (eds.) (2000) Tabloid Tales: Global Debates over Media Standards. Boulder, CO: Rowman and Littlefield.

Taylor, C. (1995) Multiculturalism and the Politics of Recognition. Princeton, NJ: Princeton University Press.

Thompson, J. (2000) Political Scandal: Power and Visibility in the Media Age. Cambridge: Polity Press.

Weber, M. (1949) The Methodology of the Social Sciences, trans. and edited by E.A. Shils and H.A. Finch. New York: Free Press.

West, C. (1993) 'The New Cultural Politics of Difference', pp. 203-17 in S. During (ed.) The Cultural Studies Reader. London: Routledge.

Wright, C.R. (1974) 'Functional Analysis and Mass Communication revisited', pp. 199-205 in J. Blumler and E. Katz (eds.) The Uses of Mass Communication. Beverly Hills: Sage.

Young, I. (1996) 'Communication and the Other: Beyond Deliberative Democracy', pp. 120-36 in S. Benhabib (ed.) Democracy and Difference. Princeton, NJ: Princeton University Press.

Young, I. (1997) 'Difference as a Resource for Democratic Communication', pp. 383-406 in J. Bohman and W. Rehg (eds.) Deliberative Democracy: Essays on Reason and Politics. Cambridge, MA: MIT Press.

Zelizer, B. and S. Allan (eds.) (2002) Journalism after September 11. London: Routledge. 
Este artigo foi publicado anteriormente na revista Media, Culture \& Society.

Sign up for Contents Alerting Now! http://mcs.sagepub.com

\section{Media, Culture \& Society}

Editors

Raymond Boyle University of Glasgow, UK

John Corner University of Liverpool, UK

Nicholas Garnham

The University of Westminster, London, UK

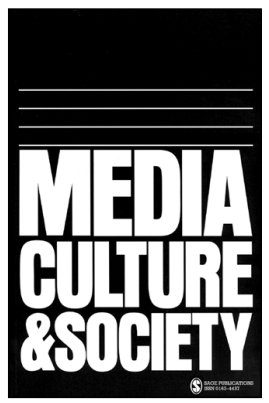

Anna Reading South Bank University, London, UK

Paddy Scannell The University of Westminster, London, UK

Philip Schlesinger University of Glasgow, UK

Colin Sparks The University of Westminster, London, UK

Media, Culture \& Society provides a major international forum for the presentation of research and discussion concerning the media, including the newer information and communication technologies, within their political, economic, cultural and historical contexts.

\section{Interdisciplinary Coverage}

The journal is interdisciplinary, regularly engaging with a wider range of issues in cultural and social analysis. Its focus is on substantive topics and on critique and innovation in

theory and method.

\section{Thematic Sections}

Media, Culture \& Society contains thematic sections on key areas of current research, providing an in-depth analysis by some of the leading scholars in the field. Recent themes covered include: Chinese transitions, media and market-places, media, nation and political culture and telecommunications.

\section{Free online sample copy available!} http://mcs.sagepub.com

Six times a year: January, March, May, July, September, November ISSN: 0163-4437

Subscription Hotline +44 (0)20 73248701 Email subscription@sagepub.co.uk

\section{\$SAGE Publications}

\section{www.sagepublications.com}

